\title{
Leucocyte ascorbic acid and pressure sores in paraplegia
}

\author{
BY R. G. BURR AND K. T. RAJAN* \\ National Spinal Injuries Centre and Rheumatism Research Centre, \\ Stoke Mandeville Hospital, Aylesbury, Buckinghamshire
}

(Received 23 February $1972-$ Accepted I March 1972)

\begin{abstract}
I. Leucocyte ascorbic acid concentration was measured in ninety-one paraplegic patients and in forty-one control subjects. Patients and controls were subdivided into males and females, and into smokers and non-smokers.

2. For each subgroup, mean results were lower in the patients than in the controls and lower in patients with pressure sores than in patients without pressure sores. The leucocyte ascorbic acid concentrations of patients were significantly lower than those of the corresponding controls for the male smokers with sores, the female non-smokers with sores and the female non-smokers without sores. Leucocyte ascorbic acid concentration was less than $15 \mu \mathrm{g} / 10^{8}$ white blood corpuscles in $23 \%$ of the paticnts studied.

3. The pressure sores of seven patients were studied by biopsy before and after the administration of $0.5 \mathrm{~g}$ ascorbic acid twice daily for $3 \mathrm{~d}$.

4. The samples from the second biopsy stained more intensely for collagen than those from the first. In three other patients studied similarly but given a placebo this effect was not observed.
\end{abstract}

In scurvy the healing of wounds is grossly impaired owing to failure of collagen synthesis. Deficiency of ascorbic acid must be severe before healing is inadequate but stresses of various kinds increase the requirement for vitamin C. There is evidence that impaired collagen formation in scurvy is related to the concentration of ascorbic acid available in the tissue but the findings relating the quality of healing to the degree of tissue saturation are not conclusive (Gould, I963; Schwartz, I970).

In previous studies (G. H. Ungar, personal communication; Hunter \& Rajan, I97I) urinary saturation tests have revealed mild vitamin $C$ depletion in some paraplegics. In addition, large oral doses of ascorbic acid given to two patients resulted in a marked increase in the collagen content of connective tissue at the edge of their pressure sores (Hunter \& Rajan, I97I).

The present work was undertaken with a view to extending these observations to a larger number of patients using leucocyte ascorbic acid (LAA) concentration as a measure of tissue saturation in the hope of further defining the relationship between vitamin $\mathrm{C}$ and wound healing. LAA concentration is accepted as the best index of body stores of vitamin C (Booth \& Todd, I970; Schwartz, I970) and does not alter with age, but is lower in men than in women, and in smokers than in nonsmokers (Brook \& Grimshaw, I968).

\section{EXPERIMENTAL}

LAA concentration was measured in ninety-one paraplegic patients, fifty-two male and thirty-nine female, aged ro-72 (mean $35^{\cdot 2}$ ) years, of whom only four lay

* Present address: Medical Research Council Pneumoconiosis Research Unit, Llandough Hospital, Penarth, Glamorganshire. 


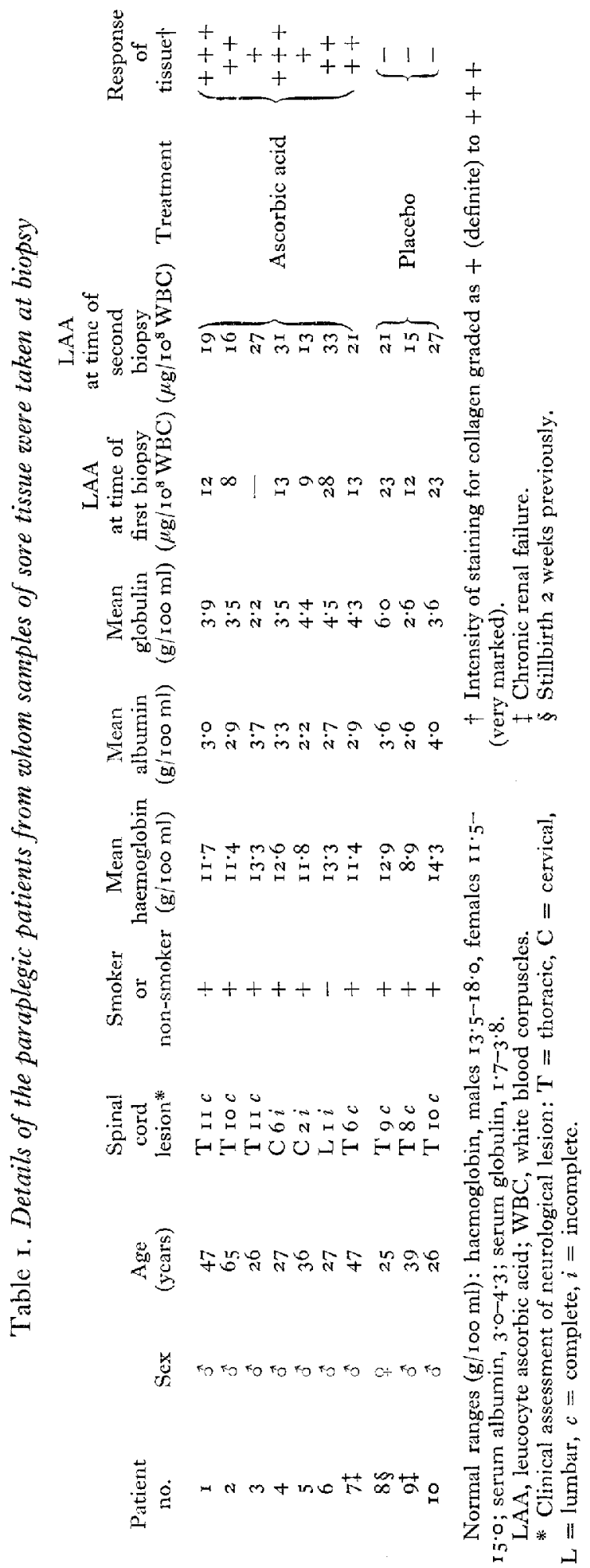


outside the range $17-65$ years. Thirty-three of the patients studied (twenty male and thirteen female) had pressure sores. Forty-one members of the hospital staff, twenty male and twenty-one female, acted as control subjects.

Ten of the patients with sores were studied by biopsy before and after a course of $500 \mathrm{mg}$ ascorbic acid, or a placebo, given twice daily for $3 \mathrm{~d}$. One (patient 6 ) was a 27 -year-old man who had developed a small sacral sore ro weeks after becoming paraplegic. The others had been paraplegics for 2-2 I years and had been admitted to the National Spinal Injuries Centre for treatment of their sores. Details of the patients studied are given in Table $\mathbf{I}$.

Biopsy consisted of the excision of a small wedge of tissue from the edge of the sore. The second biopsy sample was taken from the same sore and from an area similar to, but not immediately adjacent to, the first. At the same time a sample of venous blood was taken for measurement of haemoglobin, serum protein and LAA concentration. The tissue was fixed in formol saline and $6 \mu \mathrm{m}$ sections were stained with haematoxylin-eosin, toluidine blue and azan-aniline blue to show the collagen content and pattern of fibrous tissue.

The first five patients from whom biopsy samples were taken received one $500 \mathrm{mg}$ tablet of ascorbic acid twice daily. Of the remaining five patients, two received two gelatine capsules containing $25^{\circ} \mathrm{mg}$ ascorbic acid twice daily, and three received the same number of identical capsules which contained lactose instead of ascorbic acid. The gelatine capsules were coded and the coding was unknown to the observer (K.T.R.) examining the tissue sections. The two biopsy samples from each patient were compared and an increase in the intensity of staining for collagen was graded as + (definite) to +++ (very marked). No change or doubtful was recorded as - .

LAA concentration was determined by the method of Denson \& Bowers (I96I) using Dextran Grade A of molecular weight 200000-250000 (British Drug Houses Ltd, Poole, Dorset); blood haemoglobin and leucocyte counts were measured by Coulter Counter Model S, and total protein and albumin in an AutoAnalyzer (Technicon Instruments Co. Ltd, Basingstoke, Hants).

\section{RESULTS}

Table 2 shows the results of the LAA determinations. Patients and control subjects were subdivided on the basis of smoking habits and sex, and in addition the patients were grouped into those with pressure sores and those without. Statistical significance was tested for using Student's $t$ test. In the control subjects mean results for males were lower than for females and they were lower for smokers than for non-smokers, but the difference was significant only in that female non-smokers had significantly higher LAA concentrations than male non-smokers $(P<0.05)$. Comparison of each group of patients with the corresponding controls reveals that mean results were lower in the patients than in the controls and lower in the patients with pressure sores than in those without sores. LAA concentrations of the male patients with sores who smoked were significantly lower than those of the corresponding control subjects $(P<0.05)$, and the same was true of the non-smoking female 
Table 2. Mean values and their standard errors for leucocyte ascorbic acid concentrations ( $\mu \mathrm{g} / \mathrm{1}^{8}$ white blood corpuscles) in paraplegic patients and their controls before treatment

\begin{tabular}{|c|c|c|}
\hline Patients & Non-smokers & Smokers \\
\hline \multicolumn{3}{|l|}{ Males } \\
\hline Controls & $25 \cdot 10 \pm 1 \cdot 03, n=10$ & $21.00 \pm \mathrm{I} \cdot 77, n=10$ \\
\hline Patients without sores & $22 \cdot 14 \pm 1 \cdot 48, n=22$ & $19.00 \pm \mathrm{x} \cdot 68, n=$ I0 \\
\hline Patients with sores & $2 \mathrm{I} \cdot 33 \pm 2 \cdot 35, n=9$ & I5.1 $8^{*} \pm \mathrm{I} \cdot 97, n=\mathrm{II}$ \\
\hline \multicolumn{3}{|l|}{ Females } \\
\hline Controls & $32 \cdot 80 \pm 2 \cdot 99, n=$ I0 & $25 \cdot 64 \dagger \pm \mathrm{I} \cdot 73, n=\mathrm{Ir}$ \\
\hline Patients without sores & $22 \cdot 60^{*} \pm 3 \cdot 37, n=7$ & $25.27 \pm \mathrm{I} \cdot 8_{3}, n=\mathrm{Ir}$ \\
\hline Patients with sores & $2 \mathrm{I} \cdot 86^{*} \pm \mathrm{I} \cdot 93, n=\mathrm{I}_{5}$ & $20 \cdot 67 \pm 2 \cdot 23, n=6$ \\
\hline
\end{tabular}

patients both with and without pressure sores $\left(P<0^{\circ} 0_{5}\right)$. LAA concentration was not related to the patient's age, to the duration of the paraplegia or to the level of the spinal cord lesion.

The LAA concentrations of the patients from whom biopsy material was obtained are given in Table $\mathrm{I}$. Before treatment the LAA concentrations were in the range $8-28 \mu \mathrm{g} / \mathrm{I}^{8}$ white blood corpuscles (WBC). The biopsy samples obtained from the patients given ascorbic acid all showed a positive histological response, although it was confined to the connective tissue immediately adjacent to the epithelium and was not observed in the deeper tissue. The degree of response was not related to the initial or final LAA concentration or to the difference between them, nor was it related to the serum protein or blood haemoglobin concentrations. No response was observed in the biopsy material from the patients given the placebo.

Typical histological pictures before and after the administration of ascorbic acid are shown in $\mathrm{Pl}$. I $(+++$ response $)$.

\section{DISCUSSION}

\section{$L A A$ concentrations in paraplegia}

The numbers of subjects in the control groups were small but the LAA values obtained agree well with those reported by Brook \& Grimshaw (I968) using the same method.

The results obtained for the patients confirm the findings in an earlier experiment using urinary saturation tests in which the time taken to reach saturation in controls, paraplegics without sores and paraplegics with sores was $2 \cdot 5,4 \cdot 3$ and $5 \cdot 4 \mathrm{~d}$ respectively (Hunter \& Rajan, I97I). Other workers have found that LAA concentrations were lower in patients who had been in hospital for a long time than in patients who had been in for only a short time, and that elderly persons living in institutions had lower LAA concentrations than those living at home (Booth \& Todd, I970). The tissue concentration of vitamin $\mathrm{C}$ in the paraplegics studied by us was similar to that reported for the 'long-stay' patients, and the paraplegics at this Centre are probably a typical in-patient population in this respect.

Children with spina bifida have been observed to have subclinical deficiency of 
Table 3. Numbers of paraplegic patients having leucocyte ascorbic acid (LAA) concentrations below $5 \mu \mathrm{g} / \mathrm{IO}^{8}$ white blood corpuscles before treatment

\begin{tabular}{|c|c|c|c|c|}
\hline \multirow[b]{2}{*}{ Patients } & \multicolumn{2}{|c|}{ Non-smokers } & \multicolumn{2}{|c|}{ Smokers } \\
\hline & Total & $\mathrm{LAA}<\mathrm{I}_{5}$ & Total & $\mathrm{LAA}<15$ \\
\hline \multicolumn{5}{|l|}{ Males } \\
\hline Controls & IO & $\circ$ & 10 & $2(20 \%)$ \\
\hline Patients without sores & 22 & $4(18 \%)$ & IO & $2(20 \%)$ \\
\hline Patients with sores & 9 & $3(33 \%)$ & II & $7(64 \%)$ \\
\hline \multicolumn{5}{|l|}{ Females } \\
\hline Controls & ro & 0 & I I & 0 \\
\hline Patients without sores & I 5 & $2(13 \%)$ & I I & 0 \\
\hline Patients with sores & 7 & $3(43 \%)$ & 6 & $\circ$ \\
\hline
\end{tabular}

vitamin C (McKibbin, Toseland \& Duckworth, I968), but it is difficult to relate this report to the present findings because a different method of assessing ascorbic acid status was used.

The reason for the LAA concentrations in the patients being lower than in the controls may have been partly dietary and due to loss of the vitamin during bulk preparation of vegetables (Davidson \& Passmore, 1966). Another factor may have been the stresses to which hospital in-patients are exposed. Stress is known to cause depletion of body reserves of vitamin $\mathrm{C}$, an effect which is probably mediated by corticotrophin (Beck, English, Hackney \& Mackenzie, r950; Stefanini \& Rosenthal, 1950; King, I968). A difference between patients with and without pressure sores is to be expected because after wounding there is mobilization of ascorbic acid to the wound area at the expense of the serum and other tissues of the body (Abt $\&$ von Schuching, I96r; Gould, I963; Shukla, I969).

Booth \& Todd (1970) suggested that supplementary vitamin $\mathrm{C}$ should be given when the leucocyte concentration is below $\mathrm{r} 5^{-20} \mu \mathrm{g} / \mathrm{IO}^{8} \mathrm{WBC}$. Windsor \& Williams ( 1970 ) demonstrated an increase in total urinary hydroxyproline in elderly patients given ascorbic acid when the LAA concentration was below $15 \mu \mathrm{g} / \mathrm{IO}^{8} \mathrm{WBC}$. In our patients the LAA concentration was below this value in sixteen $(3 \mathrm{I} \%)$ of the fifty-two male patients and in five ( $13 \%$ ) of the thirty-nine female patients (see Table 3). On this basis the incidence of hypovitaminosis $\mathrm{C}$ in males and females combined was $23 \%$.

The present recommended daily intake of vitamin $\mathrm{C}$ for adults is $30 \mathrm{mg}$ (Department of Health and Social Security, 1969). Crandon, Lennihan, Mikal \& Reif (I96r) recommended $200 \mathrm{mg} / \mathrm{d}$ to cover the stresses of surgery. This level of intake may also be indicated for paraplegic patients.

\section{Vitamin $C$ and the healing of pressure sores}

In experimental studies of wound healing in animals, tissue collagen content is measured by chemical determination of hydroxyproline (after hydrolysis). This determination was not done in the present study because the biopsy samples were very small and contained varying proportions of epidermis. Care was taken to ensure 
that each pair of biopsy specimens received identical treatment for fixing and staining.

In all the seven paticnts given vitamin $\mathrm{C}$ the samples from the second biopsy stained for collagen more intensely than those from the first. It is well known that secondary wounds show accelerated healing compared with primary wounds, owing in part to increased collagen formation (Kowalewski, Russell \& Heron, 1970). In the three patients given a placebo there was no discernible difference between the material from the two biopsies, showing that where the effect was observed it was not produced by the trauma of the first biopsy.

A pressure sore is produced by local ischaemia followed by tissue necrosis. Healing is often very slow and is dependent on a multiplicity of factors, which may include local pressure and infection, the depth of the sore, the presence of necrotic tissue, the nutritional status of the patient, antibiotic or steroid therapy (Schiff, 1969), environmental temperature (Cuthbertson \& Tilstone, I969), and the availability of zinc (Davies, I968) and ascorbic acid. Ascorbic acid is essential for the normal metabolism of fibroblasts and is involved in the hydroxylation of peptide-bound proline. In severe vitamin $\mathrm{C}$ deficiency wound healing is impaired, but the precise relationship between the tissue concentration of ascorbic acid and the quality of healing has not been established.

Crandon et al. (I96r) found an eightfold higher incidence of wound dehiscence when the white cell/platelet content of ascorbic acid at the time of surgery was below $8 \mathrm{mg} / \mathrm{roog}$. Thus this value represents the limit of serious deficiency, but is difficult to relate to our values owing to the use of a different method. The mean value obtained by these workers in control subjects was $15.0 \mathrm{mg} / \mathrm{I} 00 \mathrm{~g}$. There is some evidence for a beneficial effect of very high dosage with the vitamin. Klemm ( 1967 ) found that local application of ascorbic acid produced an increase in wound tensile strength in dogs that presumably had normal tissue concentrations inasmuch as dogs normally synthesize all their needed vitamin C. Abt, von Schuching \& Roe (I959) found that guinea-pigs given $90 \mathrm{mg} / \mathrm{d}$ had a greater wound tensile strength than animals maintained on $30 \mathrm{mg} / \mathrm{d}$, although the lower dose was sufficient to produce tissue saturation, and the main increase in wound strength was obtained in going from o to $6 \mathrm{mg} / \mathrm{d}$.

The dosage of vitamin $\mathrm{C}$ given in this study, $\mathrm{I} \mathrm{g} / \mathrm{d}$, was ten times the amount required to maintain tissue saturation in healthy man, but was given for only $3 \mathrm{~d}$ to subjects having, with one exception, a subnormal tissue concentration initially. The histological response obtained indicates a definite effect of vitamin $\mathrm{C}$ on collagen formation at all concentrations of LAA, but this effect cannot be equated with acceleration of wound healing without more evidence. Granulation tissue may be stronger in the presence of increased ascorbic acid concentration, but may not be produced any faster owing to the limiting effect of other factors, some of which are listed above, and there may be others as yet unrecognized. A controlled trial in a large group of patients, involving serial measurements of the size of the sore, and the use of different dosages, will be necessary in order to demonstrate that slight ascorbic acid deficiency retards healing, that large doses of vitamin $\mathrm{C}$ accelerate healing, or both. 

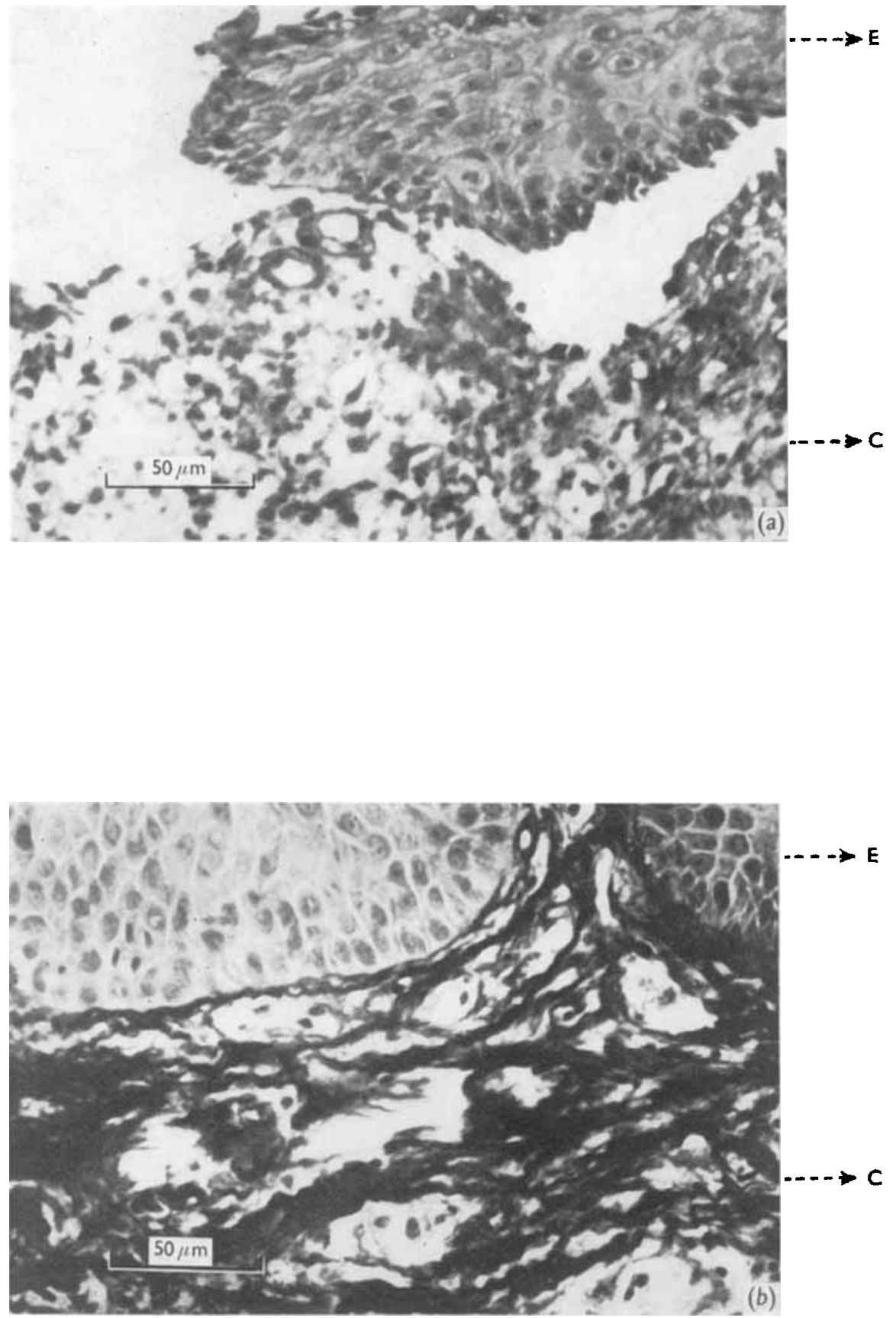
The authors wish to thank Dr A. Barr for the statistical analyses, Dr L. C. A. Nunn for the serum total protein and albumin determinations, Dr C. S. Pitcher for the blood haemoglobin measurements and leucocyte counts, and Dr H. L. Frankel for reading the manuscript. The technical assistance of Miss A. Hopkins and Mrs I. Kardos is gratefully acknowledged.

\section{REFERENCES}

Abt, A. F., von Schuching, S. \& Roe, J. H. (1 959). Bull. Ұohns Hopkins Hosp. ro4, 163.

Abt, A. F. \& von Schuching, S. (r96r). Ann. N.Y. Acad. Sci. 92, 148.

Beck, J. C., English, M. M., Hackney, J. W. \& Mackenzie, K. R. (1950). F. clin. Invest. 29, 798.

Booth, J. B. \& Todd, G. B. (1970), Br. F. Hosp. Med. 4, 513.

Brook, M. \& Grimshaw, J. J. (1968). Am. F. clin. Nutr. 21, 1254.

Crandon, J. H., Lennihan, R. Jr, Mikal, S. \& Reif, A. E. (Ig6r). Ann. N.Y. Acad. Sci. 92, 246.

Cuthbertson, D. \& Tilstone, W. J. (1969). Adv. clin. Chem. 12, I.

Davidson, S. \& Passmore, R. (1966). Human Nutrition and Dietetics p. 323. Edinburgh: Livingstone.

Davies, I. J. T. (1968). $\mathscr{H} l$ R. Coll. Physns Lond. 2, 197.

Denson, K. W. \& Bowers, E. F. (I961). Clin. Sci. 21, I57.

Department of Health and Social Security (1969). Rep. publ. Hlth med. Subj, Lond, no. I20.

Gould, B. S. ( 1963$)$. Int. Rev. Cytol. r5, 301.

Hunter, T. \& Rajan, K. T. (I97I). Paraplegia 8, 2 I I.

King, C. G. (1968). Nutr. Rev. 26, 33.

Klemm, W. R. (1967). Experientia 23, 55.

Kowalewski, K., Russell, J. C. \& Heron, F. M. (1970). Can. F. Surg. r3, I96.

McKibbin, B., Toseland, P. A. \& Duckworth, 'T. (1968). Devl Med. Child Neurol. r5, Suppl. p. 55.

Schiff, M. (1969). Laryngoscope 79, 1419.

Schwartz, P. L. (I970). F. Am. diet. Ass. 56, 497.

Shukla, S. P. (Ig69). Experientia 25, 704 .

Stefanini, M. \& Rosenthal, M. C. (1950). Proc. Soc. exp. Biol. Med. 75, 806.

Windsor, A. C. W. \& Williams, C. B. (1970). Br. med. F. i, 732.

\section{EXPLANATION OF PLATE}

(a) Skin biopsy from edge of sore from a paraplegic patient at day 0 . Note sparse connective tissue under the epidermis. (b) Skin biopsy from edge of same sore at $48 \mathrm{~h}$ after $3 \mathrm{~g}$ ascorbic acid had been given orally. Note dense connective tissue under the epidermis. All tissues stained with azan-aniline blue. $\mathrm{E}$, epidermis; $\mathrm{C}$, connective tissue. 